\title{
Mountains between Sustainability and Development: Managing Sustainable Development in Mountain Areas
}

\author{
Sürdürülebilirlik ve Kalkınma Arasındaki Dağlar: \\ Dağlık Alanlarda Sürdürülebilir Kalkınma Yönetimi
}

\author{
Boian Iordanov Koulov \\ National Institute of Geophysics, Geodesy, and Geography, \\ Bulgarian Academy of Sciences, Sofia, Bulgaria
}

\begin{abstract}
The goal of this investigation is to examine sustainable development management in mountain areas. On the basis of the author's field research in the Western Rhodope Mountains of Bulgaria, this work examines the assertion that sustainable development policies are most effective when they address all salient natural and anthropogenic elements on which sustainability of the managed system depends. The research applies the system's approach to the understanding of the sustainable development concept and employs a geographic system model to reveal the guiding principles of sustainable management in mountain areas. It analyzes the necessary elements that make sustainable development possible and concludes that political and cultural aspects are paramount to understanding of the sustainable development concept. The research examines the specific dynamics of mountains' natural and anthropogenic characteristics and introduces the term "overlap of peripheries" to better explain the case of mountain areas development in Southeastern Europe. It concludes that inclusion of all elements on which sustainability depends, as well as their integrated management are guiding principles of sustainable administration. Mountains can be managed sustainably only at the "whole mountain" scale and within the boundaries of the entire geographic system. Key words: Sustainable development, mountain areas, Western Rhodope Mountains, Bulgaria.
\end{abstract}

Özet: Bu araştırmanın amacı dağllk alanlarda sürdürülebilir kalkınma yönetimini incelemektir. Yazarın Bulgaristan'ın Batı Rodop Dağları'ndaki alan araştırmasına dayalı olan bu çalı̧̧ma, yönetilen bir sistemin sürdürülebilirliği bütünüyle antropojenik ve doğal elemanlara bağlı olduğunda, sürdürülebilir kalkınma politikalarının en etkili olduğu iddiasını incelemektedir. Araştırmada, sürdürülebilir kalkınma kavramının anlaşılmasında sistemin yaklaşım modelini kullanılmıș ve dağlık alanlardaki sürdürülebilir yönetimin temel ilkelerini ortaya çıkarmak için bir coğrafi sistem modeli kullanılmıştır. Araşsırma, sürdürülebilir kalkınmayı sağlayan gerekli elemanları açılar ve sürdürülebilir kalkınma kavramının anlaşılmasında politik ve kültürel özelliklerin büyük öneme sahip olduğu sonucuna ulaşır. Araştırma dağların doğal ve beşeri özelliklerinin özel dinamiklerini inceler ve Güneydoğu Avrupa'daki dă̆ alanlart gelişsimi olgusunu daha iyi açıklamada "dış sınırların örtüşmesi” terimini tanıtır. Araştırmada bu alanların bütünleşik yönetiminde, sürdürülebilir yönetimin temel ilkeleri olduğu kadar sürdürülebilirliğin bă̆lı olduğu bütün elemanları içermesi gerektiği sonucuna varılmıştır. Dağlar sürdürülebilir olarak yalnızca "dağ bütünü” ölçeğinde ve tüm coğrafi sistemin sinırları içinde yönetilebilir.

Anahtar sözcükler: Sürdürülebilir kalkınma, dağlık alanlar, Batı Rodop Dağları, Bulgaristan.

\section{Introduction}

Practical implementation of the sustainable development concept necessarily raises the questions of the geographic scale at which the respective policies and instruments should be targeted, as well as the boundaries within which they should be executed to maximize effectiveness. Research on environmental sustainability management of the Black Sea (Koulov, 2012) posits that sustainable development is most effective when its policies include all salient natural and anthropogenic elements on which sustainability of the managed system depends. This investigation's main goal is to examine the relevance of this conclusion to mountain areas on the basis of the author's field research in the Western Rhodope Mountains of Bulgaria. 


\section{Boian Iordanov Koulov}

The first section of this work identifies the elements that are necessary to make sustainable development possible. The second section analyzes mountains as objects of sustainable development management. It analyzes the specific natural and anthropogenic characteristics which make mountains particularly relevant objects of global sustainable regional development, in terms of both research and social policy. The third section addresses geographic aspects of sustainable regional development management of mountain areas, including "the most effective" scale and boundaries of the managed region.

This research studies several significant bodies of literature: works on regional and local sustainable development in the EU and Bulgaria, political environmental geography (e.g., Dietz 1996), the effects of mountains and political borders on economic and social development (e.g., Borsdorf et al., 2010), integrated watershed management (e.g., Heathcote, 2009; Gregersen et al., 2007; Randhir, 2007), as well as the regionalization research.

\section{Elements of Sustainable Development}

Sustainable development is often misinterpreted and reduced to three elements or "pillars": environmental, economic and social. In the final document of the UN-organized World Summit in 2005, for example, two of these - the economic and the social "pillars" - are associated with development, while the third is referred to as "environmental protection." (Anonymous, 2005). Critical analysis of this understanding demonstrates that even in the 21st century, many state leaders believe that it is possible and even "sustainable" for contemporary society to continue to develop economically and socially, while nature remains in "balance". This view places standards of living in exclusive dependence on economic and technological development. The importance of nature to human wellbeing is seriously underestimated, as well as the role of the natural factors as basis for economic and social development. Ignored are the questions of the balance among the different elements of sustainable development, as well as the spatial and temporal contexts in which this process takes place.

In fact, even the Stockholm Declaration of 1972 presents human environment as a much more complex system of interconnected elements - historical (temporal), geographic (geo-spatial), economic, social, political (domestic and foreign policy), managerial, cultural, ethical (Anonymous, 1972). System analysis proves that each of these elements is absolutely necessary for sustainable development of human society. The historical element, for example, reflects the time limitations on the use of resources like land, drinking water, soil, and petroleum. It points to the possibility of their exhaustion with severe negative consequences for the development of mankind. This aspect also concerns the relationship between present and future generations in terms of their rights to satisfy their needs for natural resources.

The geographic element of sustainable development relates to the full spectrum of "nature society" relations. It addresses the contradiction between the increasing needs of growing human society and the scarcity of natural resources, including geographic space. On a planetary scale, this limitation is expressed in the stipulation that resources are used in such a way that meets the needs of all humanity. Principles 3 and 6 of the above Declaration explicitly emphasize the fact that environment has a certain, limited capacity. Among of the most important ongoing tasks of geography in this respect are monitoring, assessment, and prediction of the effects of the unsustainable relationships between nature and society on this planet, and, in the short term, to monitor and predict the impact of unsustainable development that a region might have on the development of other, mostly neighboring regions.

Social and political elements of sustainable development are also duly noted in the Declaration's principles (Principles 5 and 6). The vast differences in resource use among and within countries and social groups produce intrastate and interstate conflicts, terrorist acts, and threaten

human lives and livelihoods. Economic, political, and governance aspects of sustainable development are well illustrated in the conclusion: 


\section{Mountains between Sustainability and Development: Managing Sustainable Development in Mountain Areas}

"To defend and improve the human environment for present and future generations is imperative goal for mankind, a goal that must be pursued together with, and in harmony with the established and fundamental goals of peace and global economic and social development." (Anonymous, 1972).

The 1972 Stockholm Declaration considers also ethical issues, including the fundamental right to life, in the light of sustainable development. It emphasizes that "Both natural and anthropogenic environment are essential for human well-being and the enjoyment of fundamental human right - the right to life." (Anonymous, 1972). The very first principle of this document leads directly to the most often quoted definition of sustainable development, which later came up in the 1987 Brundtland Report (Anonymous, 1987). According to it, inter-generational justice requires that meeting the needs of modern society should not deprive future generations of the right to meet their needs.

Culture was first introduced as yet another important element of the sustainable development model at the Rio Conference (1992). The associated Convention on Biological Diversity highlighted for the first time at the international level the importance of preserving and maintaining the so-called "indigenous" or "traditional" knowledge, innovations and practices for conservation and sustainable use of biodiversity (Anonymous, 1992).

This analysis amply demonstrates that, not only economic, social, and environmental, but also political and cultural elements are paramount to understanding of the sustainable development concept. At the current level of development of human society, all aspects of "nature - society" relations have to be considered in an integrated fashion, so that the Earth's surface can continue to sustain human development. The perception of integrated natural and anthropogenic elements, which make up the Earth's surface, attests to the fundamentally geographic nature of the sustainable development process and, at the same time, allows for application of the systems approach to its objects.

\section{Mountains as Objects of Sustainable Development}

Mountains are predominantly natural systems, while urban areas - predominantly anthropogenic. As terrain elevation increases, geographic elements change to acquire specific natural and anthropogenic characteristics that turn mountain areas into a part of human geography's periphery. Population density generally decreases with the increase of altitude. The vast majority of world's population inhabits the coastal areas. Thus, from the vantage point of the urban areas, mountains are part of the land periphery: they are some of the largest, least anthropogenized areas of the Earth's land surface, which makes them particularly relevant objects of sustainable development.

One of the most salient characteristics of mountains as objects of sustainable development originate in the significant geographic space they occupy - about 27 percent of the Earth's land surface (Anonymous, 2011). At the same time, mountains are rich in natural resources, particularly water and forests, that are also much better preserved in comparison with other areas. Up to 80 percent of Earth's fresh surface water comes from mountain regions (Anonymous, 2011). Mountains are also some of the largest producers of Eco-services. Biodiversity and cultural diversity are also dis proportionally higher compared to the rest of the land area. Almost half the world's biodiversity hotspots are in mountain areas, which also serve as culture repositories of global significance. Local cultures are represented by relatively smaller groups and include lifestyles that much more closely reflect features of the natural landscape. These cultural groups are quite rich in specialized knowledge and, due to their peripheral position, generally, less exposed to change. In this sense, mountains serve as a vital link which maintains and sustains the nature-society relationship.

Due mostly to their specific relief, mountains are relatively inaccessible, scarcely populated, and less economically developed. Settlements in those areas are smaller, sparse, and more dispersed. Mountain areas sustain fewer socio-economic functions, including smaller number of social services, 


\section{Boian Iordanov Koulov}

higher unemployment, greater vulnerability to exploitation, and lower living standards. The population is generally poor - some 80 percent of the people live below the poverty line (Anonymous, 2011). While only about 12 percent of the world's population lives in the mountains, over 50 percent of them are directly or indirectly dependent on mountain resources. The representative economic activities belong mostly to the primary sector - agriculture, forestry, quarrying, tourism, and local crafts - and their assortments are quite limited. Economic development most often relies on extensive methods of resource use, which increases mountain's vulnerability to resource depletion, e.g., deforestation, biodiversity and soil loss, poaching, landslides, and forest fires and ascribes such areas to the socioeconomic periphery.

The contradiction between the need for natural resource protection at national and global scale and the economic and social development needs of the local population is yet another characteristic feature of resource use in mountain areas. Nature protection regulations too often constrict local population's access to resources. This author's field work in the Pirin and the Western Rhodope Mountains of Bulgaria testifies to multiple examples to the conclusion above (Koulov, 2012).

Mountains make up the political peripheries of many countries: quite often they serve as boundaries between states or their internal administrative units. Europe, in particular, accommodates $50 \%$ of the world's top 20 countries with the highest percentage of mountainous areas. The European states can be further subdivided in two groups with sharply different standards of living. Five of them Albania, Bosnia and Herzegovina, Macedonia, Montenegro, Slovenia, and Turkey - are concentrated in the southeastern periphery of the continent, also called the Balkans. Political entities and boundaries continue to proliferate in this region, sometimes even accompanied by military conflicts with all negative consequences for nature, economy, and societies. The standard of living in this group of states, measured by GDP on a purchasing power parity basis for 2011 in current US dollars, is the lowest in Europe. It varies between $\$ 7,800$ and $\$ 14,700$, with the exception of Slovenia $(\$ 29,000)$ (Anonymous, 2012). Their economic position, therefore, also makes the region the most pronounced part of Europe's periphery.

The second European group of the world top 20 most mountainous states - Andorra, Liechtenstein, Switzerland, and Austria - takes the other end of the political and economic spectrum. Their standard of living varies between $\$ 37,200$ and $\$ 43,900$ with exception of Liechtenstein $(\$ 141,100)$ (Anonymous, 2012). A task of considerable interest for European and even global mountain areas research is to compare the two groups of states in terms of their sustainable development levels. Transfer of both economic development and environmental mitigation and adaptation know-how and policies should be an important instrument in EU's neighborhood strategy.

The lacking or insufficient trans-border environmental cooperation and institutional capacity in mountain areas add to the proliferation of political and administrative boundaries to further constrict economic development and, at the same time, damage environmental sustainability. Evidence of that exists even between EU Member States. Assenov (2012) reports on nature protection measures in Bulgaria that differ from those in neighboring areas with the same characteristics across the border with Greece. Apparently, such developments serve nature protection and sustainable development neither in these countries, nor in the EU as a whole.

In summary, each characteristic of the Earth surface - from the environmental through the economic to the political - change in mountain regions in ways, which turn these areas into socioeconomic periphery. The analysis of these interrelated and interdependent changes reveals a phenomenon that can be described as "overlap of peripheries". In the case of mountain regions, the term denotes an area where peripheries of both different nature (economic, political, etc.) and/or geographic scale overlap. The phenomenon additionally intensifies the negative effects on the sustainability of development in mountain areas. At the same time, it provides further arguments for mountains to become priority objects of global sustainable development policies. 


\section{Managing Sustainable Development in Mountain Regions: A Geographic System Model}

The implementation of the sustainable development concept in the practice of regional management necessarily raises the questions of the geographic scale at which the respective policies and instruments should be targeted, as well as the boundaries within which they should be executed to maximize effectiveness. Research on environmental sustainability management of the Black Sea (Koulov, 2012) posits that sustainable development is most effective when its policies include all salient natural and anthropogenic elements on which sustainability of the managed system depends. To test the relevance of this conclusion to mountain areas, this investigation employs the systems approach to modeling the respective sustainability elements and processes.

The geographic essence of the sustainable development concept and the closely interrelated and interdependent nature and functioning of its elements in mountain regions are conducive to the claim that, to achieve sustainable development, the object of management - the area, i.e., the managed subsystem - should be modeled after a geographic system. These types of systems by definition include all aspects of "nature-society" relations and at the same time possess a degree of unity: qualities, which create the conditions for these systems to achieve and/or uphold dynamic sustainability. Thus, the administration of a sustainable mountain system should rest on the principles of all inclusive and integrated management. Instead of focusing attention on the economically important resources, like water and forests, the managing subsystem has to necessarily employ, firstly, all salient natural and anthropogenic elements on which sustainability in the particular mountain area depends and, secondly, direct their functioning in an integrated fashion.

Identification of the scale and geographic boundaries of the managed area (i.e., the managed subsystem) that would be most "appropriate" for sustainable development purposes presents another important aspect of effective regional management. The ultimate object of sustainable development management is Earth's cover - the anthroposphere. The lower scales of the managed subsystem, however, are more disputed, often even controversial. The problem is that sustainable management policies are generally implemented to areas with boundaries drawn for a different purpose. For that reason mainly, integrated management has been proposed for different geographic scales, e.g., sea and river watersheds, coastal zones (e.g., see Heathcote, 2009; Gregersen et al., 2007; Randhir, 2007).

Similarly, mountains are generally split among a number of administrative regions, quite often of different scale and rather conservative nature. Historically, sustainable development has never been among their objectives. Currently, a discrepancy exists between sustainable regional development goals and the geographic boundaries, within which they are to be executed.

New development goals, new modes of functioning of the "nature - human society" system can only be realized through novel management structures which will necessarily acquire respective geospatial forms. General cybernetics principles require that the boundaries of the managing system coincide with those of the managed one. The incongruity between the managed subsystem and the managing subsystem's objectives can only be overcome through adjustment of the scale and boundaries of the managed subsystem: special purpose regionalization is needed in mountain areas to identify sustainable development regions. Moreover, periodical redistricting should necessarily take place, since elements and conditions of sustainability on the ground constantly change. Thus, rather than administering areas, which have been designed for other purposes, the proposed geographic system model presumes regions which possess particular characteristics.

The model's implications for the scale of sustainable development management suggest that the "mountain" scale is most salient for the respective geographic systems. The boundaries, within which mountains can be managed sustainable, are those of the whole, comprehensive geographic 


\section{Boian Iordanov Koulov}

system. The areas that these boundaries define possess a degree of completeness: they include all salient sustainable development elements. The objects of sustainable development, i.e., the managed subsystems, thus acquire particular systemic characteristics, wholeness properties, which are vital for their integrated management.

\section{Conclusion}

This research demonstrates that, in addition to the economic, social, and environmental elements, political and cultural aspects are paramount to understanding of the sustainable development concept. All aspects of "nature - human society" relations have to be considered in an integrated fashion, so that the Earth's surface can continue to sustain human development.

Geographic characteristics change in mountains in ways, which often turn these areas into socio-economic periphery and, as such, into objects of sustainable development policies. At the same time, mountains occupy $-27 \%$ of the Earth's land area, which makes them the most important global object of regional development policies. To better explain the case of mountain areas development in Southeastern Europe, this research describes it as "overlap of peripheries". In such areas, peripheries of different nature (economic, political, etc.) and/or different geographic scales overlie each other, which additionally intensifies the negative effects on their sustainable development. At the same time, this phenomenon provides extra arguments for mountains to become priority objects of global and regional sustainable development policies.

The analysis of the sustainable development concept and the closely interrelated and interdependent nature and functioning of the sustainable development elements in mountain regions lead to the conclusion that the object of sustainable management - the managed area - should be modeled after the respective mountain geographic system. The geographic system management model warrants that guiding principles of sustainable administration of a mountain system will be inclusion of all elements on which sustainability depends, as well as their integrated management. Regionalization, based on this model, will solve the current discrepancy between sustainable regional development goals and the geographic boundaries, within which they are to be executed. Mountains can be managed sustainable only within the boundaries of the whole, comprehensive geographic system. Thus, the "whole mountain" scale is most "appropriate" for the purposes of sustainable development management.

\section{Acknowledgement}

This research is supported by the "Academic Dialogues and Innovation" Program of the "Alma Mater" University Complex for the Humanities at Sofia University "St Kliment Ohridski " and funded by the Ministry of Education, Youth, and Science Scientific Research Fund. 


\section{Mountains between Sustainability and Development: Managing Sustainable Development in Mountain Areas}

\section{References}

Assenov, A. Environmental Protection and Political Borders: Natura 2000 in the Rhodope Mountains. "Mountain Resources and their Response to Global Change", SEEmore Conference, Ankara 5-8 July 2012.

Borsdorf, A., Grabherr, G., Heinrich, K., Scott, B., and Stötter, J. (eds.) 2010. Challenges for Mountain Regions - Tackling Complexity. Vienna: Böhlau.

Dietz, T. Entitlements to Natural Resources: Contours of Political Environmental Geography. 1996. Utrecht: International Books, 80 pp.

Gregersen, H., Ffolliott, P., and Brooks, K. Integrated Watershed Management: Connecting People to Their Land and Water. 2007. Oxfordshire, UK and Cambridge, MA: CAB International, $210 \mathrm{pp}$.

Heathcote, I. Integrated Watershed Management: Principles and Practice. $2^{\text {nd }}$ ed. 2009. Hoboken, NJ: John Wiley \& Sons, Inc., $456 \mathrm{pp}$.

Koulov, B. Sustainable Environmental Management of Marine Regions: The Black Sea Case Study. 2012. Geoadria, 17:1, 311.

Randhir, T. Watershed Management: Issues and Approaches. 2007. London: IWA Publishing, 158 pp.

Author's Field work in the Western Rhodope Mountains of Bulgaria, 2012.

Anonymous. 2012. CIA World Factbook, https://www.cia.gov/library/publications/the-world-factbook/fields/2004.html, accessed on 04.09. 2012

Anonymous. 2011. UN Food and Agriculture Organization, http://www.fao.org/forestry/28810/en/, , accessed on 04.09. 2012.

Anonymous. 2005. World Summit Outcome Document, World Health Organization, 15 September 2005.

Anonymous.1992. Convention on Biological Diversity, Article 8, j. United Nations. http://www.unutki.org/default.php?doc_id=47, accessed on 04.09. 2012.

Anonymous. 1972. Declaration of the United Nations Conference on the Human Environment. UNEP, UN Doc. A/Conf.48/14/Rev. 1 (1973), 11 ILM 1416 (1972),

Anonymous. 1987. Our Common Future, Chapter 2: Towards Sustainable Development. World Commission on Environment and Development.Un-documents.net. Retrieved 2011-09-28. 